\title{
Weed research issues, challenges, and opportunities in India
}

\author{
A.N. Rao ${ }^{a, *}$, Ravi Gopal Singh ${ }^{\mathrm{b}}$, Gulshan Mahajan ${ }^{\mathrm{c}}$, S.P. Wani ${ }^{\mathrm{d}}$ \\ a ICRISAT Development Center (IDC) \& International Rice Research Institute (IRRI), International Crops Research Institute for Semi Arid Tropics, Building \# 303, \\ ICRISAT, Patancheru 502324, Hyderabad, India \\ ${ }^{\mathrm{b}}$ International Maize and Wheat Improvement Center (CIMMYT), Texcoco de Mora, Mexico \\ ${ }^{\mathrm{c}}$ The University of Queensland, Queensland Alliance for Agriculture and Food Innovation, Room \# 130, Building 8103, Post Box 1218, Gatton 4343, Queensland, \\ Australia \\ d Asia Program, International Crops Research Institute for Semi Arid Tropics (ICRISAT), Patancheru 502324, Hyderabad, India
}

\section{A R T I C L E I N F O}

\section{Keywords:}

India

Weeds

Herbicides

Integrated weed management

Climate change

\begin{abstract}
A B S T R A C T
Agriculture is the major source of livelihood for nearly half of the Indian population. However, the productivity of crops is much lower than many countries and needs enhancement to produce $\sim 400$ million tons of food grains for meeting food demands of a population of 1.7 billion by 2050. Diverse climatic conditions in India favor the most adopted weeds to prevail and cause severe crop yield losses. Weeds also degrade quality of the produce, raise cost of production; harbor and serve as alternate hosts to several insect pests and diseases. Parthenium hysterophorus L.; Phalaris minor Retz.; Leptochloa chinensis (L.) Nees.; Echinochloa spp.; weedy rice; Lantana camara L.; Chromolaena odorata (L.) R.M. King \& H. Rob.; Mikania micrantha Kunth., are a few of many major weeds of concern currently in India. Weed management in India is critical to improve crops productivity by minimizing weeds caused crop yield losses and to alleviate other adverse effects of weeds in different ecosystems. In spite of the progress made in evolving weed management technologies for different crops and other ecosystems, weeds continue to be a concern in varying ecosystems. The real challenges of Indian weed research are: managing weeds in small farms; non availability of labor and mechanical tools; inadequate information on weed biology and shifts in weed flora; herbicide resistant weeds; lack of understanding on the impact of climate change on weeds and weed control; popularizing integrated weed management with herbicides use by ensuring safe use to avoid adverse effect on human health, environment and avoid weeds developing herbicide resistance and prevention of entry and management of alien invasive weeds. The greatest opportunity of Indian weed science is the potentiality of appropriate weed management technologies to substantially improve the crops productivity. Thus, weed scientists have a greater role to play in the development, popularization and adoption of location specific effective, economical and eco-friendly weed management technologies for different ecosystems of India.
\end{abstract}

\section{Introduction}

India is an agrarian economy with a large population base. Agriculture offers employment, food security, and demand for industrial goods and services. India experiences a wide range of temperatures varying from arctic cold to equatorial hot and rainfall from extreme aridity $\left(<10 \mathrm{~cm} \mathrm{year}^{-1}\right)$ to extreme humidity, with some areas recording the world's highest rainfall $\left(1120 \mathrm{~cm}\right.$ year $\left.^{-1}\right)$. Depending upon soil, bio-climate and physiography, the country has 20 agro-eco regions and 60 agro-eco-sub-regions. Each agro-eco-sub-region has further been classified into agro-eco-units at the district level for developing long term land use strategies (Gajbhiye and Mandal, 2006). The share of agriculture in the Gross Domestic Product (GDP) was 17.9 per cent in 2014-15 (http://statisticstimes.com/economy/ sectorwise-gdp-contribution-of-india.php) at constant (2011-12) prices. The share of agriculture sector in employment is 48.9 per cent of the workforce (ILO, 2016). India's population is estimated to reach 1.7 billion and the food demand is expected to rise up to $\sim 400$ million tonnes by the year 2050. India has to enhance productivity in agriculture to ensure food security for the growing population. Therefore, the Indian agricultural production system has challenge to feed $17.5 \%$ of the global population with only $2.4 \%$ of land and $4 \%$ of the available water resources at its disposal. India is the world's second largest producer of rice, wheat, and cotton, after China and the second largest producer of sugarcane, after Brazil. India is also the second largest producer of horticultural products in the world. But the productivity of crops is much lower than many countries and needs to be enhanced to meet the demands of increasing population.

\footnotetext{
* Corresponding author.

E-mail address: anraojaya1@gmail.com (A.N. Rao)
} 
Weeds account for about one-third of the total losses caused by agricultural pests (DWR, 2015). Therefore, the efforts to improved productivity in agriculture in India should include efforts to decrease losses caused by weeds. Weeds are the most severe and widespread biological constraint to agricultural production systems and cause damage in cropped and non-cropped lands. They reduce crop yield and degrade quality of the produce besides raising cost of production. In addition to yield and nutrient losses, weeds also harbor and serve as alternate hosts to several insect pests and diseases and may reduce land value. In non-cropped lands, the weeds also cause health hazards and loss of biodiversity. Indian farmers continue to experience heavy crop yield losses due to weed interference in spite of progress made in research and extension of weed science. Losses caused by weeds in agricultural crops vary because the nature, extent, and intensity of weed problems depend on the ecology in which the crop is grown and situations such as hydrology, land topography, associated environment, establishment methods and the cultural practices used. The crop loss estimates are often misleading as scientific estimates are yet to be done. Even the lowest loss estimate of $10 \%$ would amount to a loss of about $25 \mathrm{Mt}$ of food grains, currently valued at approximately US\$ 13 billion (Yaduraju, 2012). In plantation crops, fruits, vegetables, grass lands, forestry and aquatic environment also similar magnitude losses may occur. If the indirect effects of weeds on health, loss of biodiversity, nutrient depletion, grain quality etc are taken into consideration, the total economic losses will be much higher. Weeds have assumed serious magnitude in different parts of the country. Each of the agro-ecological regions and crops grown has distinct weed problems (Rao et al., 2014). In order to avoid grain losses, avoid deterioration in soil fertility and productivity, for more rationale and judicious use of the natural resources such as sun light, water and land and attain higher crop productivity, it is essential to manage weeds. Recognizing the importance of weeds, reviews on weed management in agroecosystems of India were made earlier (Joshi, 1971; Mukhopadhyay, 1993; Bhan and Sushilkumar, 1998; Yaduraju, 2012; Rao and Chauhan, 2015; Singh et al., 2016).

In this review, recent developments on weeds and weed management in varying ecosystems of India are synthesized while enumerating the challenges and opportunities in research on managing weeds in India.

\section{History of weed research in India}

Weeds are present everywhere, since the human race came into existence, as they are adapted to all adverse environments and flourish under suitable environments. Historically farmers were controlling weeds by repeated tillage, manual weeding, growing cover crops, grazing, using rotation, burning and flooding in rice etc. Sodium arsenite was first used to control Carthamus oxicantha in India during 1937 at Punjab (Rao et al., 2014). 2,4- D was introduced in India during 1948 (Mukhopadhyay, 1993) and several chemicals have been imported and tested. Some of them were quite effective in controlling certain weeds. Scientific research work on weed management in India was initiated in 1952 with the inception of all India coordinated research scheme on major crops like rice, wheat and sugarcane. In the same year (1952), the weed control section was started in the Division of Agronomy at the Indian Institute of Agriculture Sciences, New Delhi, India. In 1960, the first agricultural University was started at Pantnagar, Uttar Pradesh and later several agricultural universities were established across the country, in which Weed Science is a part of Curriculum and weed science research is being carried on. All India Coordinated Research Project (AICRP) on Weed Control was initiated in 1978 with funding from USDA-PL480 project funds, with a few centers initially and expanded to several centers in different states of India (Bhan and Sushilkumar, 1998). National Research Centre for Weed Science was established in India during 1989 at Jabalpur, Madhya Pradesh which was upgraded as Directorate of Weed Science Research in 2009 and renamed as Directorate of Weed Research (DWR) in 2014 (DWR, 2015). Since its inception, the institute is engaged in basic and strategic research on weeds and weed management. It also coordinates location-specific weed management research carried out at 23 coordinating units located at different parts of the country. DWR has been successful in bringing awareness about the importance of weeds and weed management in enhancing crop productivity and sustainability. In 1968, the "Indian Society of Weed Science" (ISWS) was established and ISWS started publishing Indian Journal of Weed Science since 1969 and is continuing successfully till to date (Chandrasena and Rao, 2017).

\section{Weeds of India and losses caused}

Weeds (terrestrial, parasitic and aquatic) interfere with crops cultivation and ecosystem resilience in addition to loss of biodiversity (displacement of native plant species), potentially productive land, grazing land and livestock production. They also cause poisoning of humans and livestock, erosion following fires in heavily invaded areas, choking of navigational and irrigation canals and reduction of available water in water bodies (Singh, 2004). The associated ecological factors influence the impact or losses caused by weeds in different ecosystems.

Abundant information is available in India on weeds in rice (Rao and Nagamani, 2010; Subudhi et al., 2015), in wheat (Punia et al., 2017), cotton (Nalini et al., 2015), sugarcane (Jeyaraman et al., 2002), groundnut (Rajendran and Lourduraj, 1999), soybean (Panneerselvam and Lourduraj, 2000), forests (Meher-Homji, 2005), road sides (Kosaka et al., 2010), aquatic bodies (Deka et al., 2013) and fodder crops (Mukherjee and Tomar, 2015), in different states of India (Munirathnam and Kumar, 2014; Duary et al., 2015). The data collected from different Indian agro-ecological regions over a period of 20 years revealed that most frequently encountered weed species number in Indian agriculture varied from 60 to 70 in humid, per-humid, subhumid, coastal and island ecosystems, 30-40 in semi-arid and 15-20 in arid ecosystems (Dixit et al., 2008). Weeds were reported to cause yield loss of $5 \%$ in commercial agriculture, $10 \%$ in semi commercial agriculture, $20 \%$ in subsistence agriculture (Choudhury and Singh, 2015) and $37-79 \%$ in dry land agriculture (Singh et al., 2016).

A Weed Atlas for major weeds in major crops in 435 districts spread across 19 states of the country was published by DWR (Dixit et al., 2008). Eight hundred and twenty six weeds species were reported to cause yield losses in India of which 80 and 198 were considered very serious and serious weeds respectively (Choudhury and Singh, 2015). Major weed species of India in different situations were given in the vision document of DWR (DWR, 2015). Major weeds are:

Crop lands: Phalaris minor Retz., Echinochloa crus-galli (L.) P. Beauv., weedy rice, Ageratum conyzoides L., Cyperus rotundus L., Cynodon dactylon (L.) Pers. and Parthenium hysterophorus L.

Non-crop lands: $P$. hysterophorus, Lantana camara L., Mikania micrantha Kunth., Mimosa invisa Martius ex Colla, Ageratum haustonianum Mill., Saccharum spontaneum L., Chromolaena odorata (L.) R.M. King \& H. Rob. and Alternanthera sessilis (L.) R. Br. ex DC.

Water bodies: Major aquatic weeds of concern in India are: Eichhornia crassipes (Mart.) Solms, Salvinia molesta Mitch., Hydrilla verticillata (L.f.) Royle, Typha angustata Bory\&Chaub. and Alternanthera philoxeroides (Mart.) Griseb.

Parasitic weeds: In several states of India parasitic weeds are infesting crops, ornamental plants, hedges and trees and are causing economic losses. Major parasitic weeds of India include: Orobanche cernua Loefl. (on tobacco, tomato, potato), Striga asiatica (L.) Kuntze (on maize, sorghum, pearl millet), Cuscuta reflexa Roxb. (on niger, greengram, blackgram, berseem, lentil, linseed chickpea) and Dendrophthoe falcata (L.f.) Ettingsh (on neem, mango, pomegranate, sugar apple). 


\section{Available weed management technologies and their adoption in key crops and cropping systems of India}

Farmers of India are combatting weeds with their experience since they started agriculture. Indian researchers concentrated their efforts mostly on herbicides based weed management strategies (Rao et al., 2014). The recommendations for weed management are being developed by state agencies, universities and being upscaled by extension agencies. The private sector, including retailers, are also promoting weed management technologies aligned with the recommendation of state agencies. Currently greater research efforts are being made on integrated weed management and on weed ecology and biology. The environmental aspects are also been evaluated to make weed management technologies safe and environmental friendly. Technologies for management of aquatic weeds (Sushilkumar, 2011; Datta et al., 2014), forest lands and public amenity areas (Rao and Chauhan, 2015), invasive (Barua et al., 2017) and parasitic species in India was recently reviewed (Rao and Chauhan, 2015) and hence are not repeated here.

\subsection{Non chemical weed management}

The most ancient method adopted for keeping weeds under check is by hand weeding. It is a common method in India, even today. This has been also supported by several researches (Rao et al., 2014). In the earliest period, unwanted plants were pulled out by hand and destroyed. Later on hand tools were developed to derive some mechanical advantage in carrying out this operation (Sridhar, 2013). With the harnessing of animal power for farming, a number of implements were designed and used for carrying out weeding operations. Currently, many machine operated weeders are available (GOI, 2012) and are being used by farmers in India. One of the main objectives of all tillage operations carried on with the help of animal power or machine power is to control weeds directly or indirectly.

We also consider many merits of non-chemical weed management over chemical weed management practices. Planting in a clean field, mechanical weeding (Sridhar, 2013), using a vigorous crop variety (Ramesh et al., 2017), modifying planting densities (Nayak et al., 2014), growing a cover crop (Bahadur et al., 2015), intercropping (Nalini et al., 2008) or relay cropping (Masood Ali et al., 2009), nutrient and water management, alleopathy (Bhadoria, 2011), harvesting and land management etc. are important factors in intensifying crop weed competition and can significantly improve crop yields (Rao and Chauhan, 2015).

Classical biological control of weeds employing natural enemies has stimulated interest as an environmentally caring and cost effective solution for the control of weeds. A number of biocontrol agents were introduced into India, but success has been limited (Jayanth, 2000; Singh, 2001). A few of the successes are given here. Zygogramma bicolorata (a leaf-feeding beetle), Epiblema strenuana (a stem-boring moth), and Puccinia abrupta var. partheniicola and P. melampodii f. sp. parthenium hysterophorae (rust fungi) were introduced in India as the biocontrol agents (Sankaran, 2017). Of these, augmentative releases of Zygogramma bicolorata has resulted in a reduction in the pathenium density and plant height with decrease in parthenium stand over a period of 3 years, in the augmented sites (Sushilkumar and Ray, 2011). The biocontrol efficacy was low, of several pathogens recorded on parthenium in India, except for Sclerotium rolfsii, (Sushilkumar and Saraswat, 2001). The way for use of fungal pathogens biological control agents to manage invasive alien weeds in India was paved with the import of the rust fungus Puccinia spegazzinii for Mikania micrantha control (Rabindra et al., 2017). Cassia uniflora, C. tora, Abutilon indicum and a few other plants were reported to have potential for competitive replacement of parthenium in India (Sushilkumar and Saraswat, 2001).

Effectiveness was reported of non chemical such as using Japanese paddy weeder for wet (drum)-seeded rice (Bera et al., 2016); twin wheel hoe weeding at 20 DAS + hand weeding at 40 DAS in maize and sunflower (Bhuvaneswari et al., 2010); hand weeding twice and manually operated weeder + hand weeding in sunflower (Satyareddi et al., 2015); hoeings at 20, 40, 60 days after sowing and at harvest of intercrops in sugarcane (Bhullar et al., 2006); soil solarization (Patel et al., 2005; Das and Yaduraju, 2008); maintaining appropriate crop rotation with legumes and non-legume crops (Das et al., 2012); growing of cover crop to suppress weeds by smothering and allelopathic effects (Bahadur et al., 2015); growing competitive cultivars in wheat (Verma et al., 2008) and rice (Kumar et al., 2013); planting pattern in sunflower (Sumathi et al., 2010); modification in sowing and planting techniques in wheat (Punia et al., 2016; Brar and Walia, 2009); maize (Angiras et al., 2010) and maize based cropping systems (Kumar et al., 2015) and lentil (Manjunath et al., 2010); changing sowing and planting time (Bahadur et al., 2015); mulching with organic residues (Verma et al., 2008a) and black polythene (Goswami and Saha, 2006); irrigation and nitrogen management (Das and Yaduraju, 2007); green and brown manuring (Singh et al., 2007). Inclusion of non-chemical methods along with chemical methods was envisaged along with the best management practices for managing weeds in India (Rao et al., 2014) and to prevent evolution and spread of HR weeds (Reddy and Jha, 2016). Evidences are available to use herbicide as a tool to reduce weed completion and to use other method to improve crop productivity.

\subsection{Chemical weed management}

In India, herbicides are being used on more than 20 million ha, which constitute about $10 \%$ of the total cropped area in the country (DWR, 2015). The pesticide market in India is relatively small (about US $\$ 1$ billion) when compared to global market (US $\$ 33$ billion). The share of herbicides is nearly $20 \%$ of the total pesticides used and is expected to grow. Although the herbicides have been in use for over 3 decades, use has increased only recently. Wheat, rice, soybean and sugarcane are the major crops of herbicide use with approximate share of 28, 20, 9 and 7\%, respectively (Yaduraju, 2012). The list of herbicides and herbicides combinations products that are approved and used in India are available (http://cibrc.nic.in/mup.htm).

The herbicides recommendations are available for different crops of India including semi dry rice (Arya and Ameena, 2016), dry-seeded rice (Rao and Nagamani, 2007), rice and wheat (Choudhury and Singh, 2015), aquatic weeds (Datta et al., 2014) and different crops (Dixit and Varshney, 2009, 2009a). An Indian perspective of herbicides residues in soil, water, plants and non-targeted organisms and human health implications were reviewed (Sondhia, 2014). In a recent publication on herbicide use in Indian agriculture, Choudhury et al. (2016), reported that in 2007, butachlor (6032 tons) and glyphosate (6003 tons) were the highest consumed herbicides in India, followed by paraquat (2068 tons), pretilachlor (2418 tons) and pendimethalin (1444 tons). Butachlor and pretilahlor in rice; isoproturon and clodinofop in wheat; imazethapyr, fenoxaprop, pendimethalin, alachlor and imazethapyr + pendimethalin in groundnut; pendimethalin and glyphosate in cotton; atrazine and 2,4-D in maize; atrazine, paraquat and 2,4-D in sugarcane; glyphosate and paraquat in tea were reported as major herbicides used in India (Choudhury et al., 2016). The consumption of butachlor (technical grade) was reported to have come down from 2699 $\mathrm{t}$ in 2005-06 to $372 \mathrm{t}$ in $2009-10$, i.e. a reduction of $85 \%$. In the rice market, pretilachlor captured a large share from butachlor. Currently, in transplanted rice, low-dose herbicides, viz. pyrazosulfuron-ethyl and bispyribac-sodium are being used in lieu of butachlor and pretilachlor. In direct-seeded rice, pendimethalin, bispyribac-sodium, cyhalofop-pbutyl, chlorimuron + metsulfuron-methyl, ethoxysulfuron, pyrazosulfuron are being used in Andhra Pradesh and Karnataka (Rao et al., 2015a). In wheat, due to development of resistance in Phalaris, a $40 \%$ reduction in use of isoproturon occurred within 5 years, from 2005 to 06 to 2009-10. Farmers shifted from isoproturon to sulfosulfuron in wheat and more recently to combination products like mesosulfuron + iodosulfuron. Punjab, followed by Uttar Pradesh, Andhra 
Pradesh, Maharashtra and West Bengal were reported as the states of highest consumption of herbicides. The productivity need to scaled up to strengthen food security and the demand for herbicides is expected to grow substantially due to increasing labour scarcity and cost. The lack of awareness about herbicides amongst farmers and the technical competence of the extension personnel are going to be the major challenges for the scientific community to deal with. Extensive awareness-raising activities for famers and trainings and workshops for extension personnel will be urgently needed. With the increased use of herbicides, the issues such as herbicide residues in soil, water and food, resistance to herbicides in weeds (Sanbagavalli et al., 2000), etc. would come into prominence and India should be geared up to tackle them.

\subsection{Integrated weed management}

Weeds are difficult to manage effectively using single weed management method (mechanical, chemical, biological and cultural control tactics) as weeds are more aggressive, adaptive and persistent. Thus holistic approach involving different and integrated weed management practices are suggested sustainable crop production. Reviews are available on weed management, including integrated approaches, in wheat (Singh et al., 2013), groundnut (Jat et al., 2011; Priya et al., 2013), finger millet (Rao et al., 2015), maize (Sunitha and Kalyani, 2012), maize based cropping systems (Kumar et al., 2015), sorghum (Vijayakumar et al., 2014), cotton (Nithya et al., 2013), groundnut (Jat et al., 2011), groundnut based intercrops (Annadurai et al., 2010), mustard (Singh et al., 2013a), vegetable crops (Hussain et al., 2007), fruit, vegetable, tuber, ornamental, medicinal, aromatic and plantation crops (Chadha et al., 1997) and dryland crops (Singh et al., 2016). Management aspects were reviewed for problematic weeds such as $P$. hysterophorus, Cuscuta spp., Orobanche spp., Striga spp. and E. crassipes (Trivedi et al., 2000). A change in rice establishment method from traditional manual transplanting of seedlings to direct-seeding is occurring in parts of India like Karnataka, Andhra Pradesh, Punjab and Haryana, in response to rising production costs, especially for labor and water. Direct-seeded rice needs less (34\%) total labor requirement with saving of $29 \%$ of the total cost compared to transplanted rice (Rao et al., 2007). At research farms, the direct-seeding of rice has been shown to do as well as transplanted rice provided the weeds are effectively controlled. However, the spread of the technology has been restricted amongst other factors, because of absence of effective herbicides and integrated weed management strategies for weed control in directseeded rice. A summary of economic weed management strategies in India has revealed that herbicides in combination with hand weeding were most economical (Rao and Nagamani, 2010).

\subsection{Weed management and conservation agriculture}

The key elements of conservation agriculture (CA) include no-tillage, adequate retention of crop residues on the soil surface for mulching, and diversified and intensified crop rotation. Farmers can save from 30 to $40 \%$ of time and labor with CA adoption (Hobbs and Gupta, 2003). CA has been also advocated as an important way forward to mitigate and adapt climate change effects (FAO, 2017; CGIAR, 2017; ICARDA, 2017). CA covers nearly 157 million hectares i.e. $11 \%$ of the world's arable land area (CGIAR, 2017) and is becoming popular among farmers in India too, due to favorable economics of production (Ladha et al., 2016). Weeds are considered most important factors in large scale adoption of CA, as tillage was the main tool to control weeds since the inception of agriculture.

Zero tillage, a component of CA, has become popular and is practiced over $2.1 \mathrm{~m}$ ha area in wheat crop in rice-wheat system in the north western Indo-Gangetic Plains. Despite the demonstrated advantages of conservation tillage, the technology is yet to take off due to several factors including the non performance of available herbicides under farmers conditions due to several factors on the field and limited accessibility of the proper machinery. Integration of different weedmanagement strategies such as planting a weed-competitive cultivar in narrow rows with high seeding rates and use of residue as mulch and an effective post-emergence herbicide were suggested to maintain sustainability of CA systems through effective weed management in CA systems (Chauhan and Mahajan, 2012). CA and weed management are discussed in detail elsewhere (Subbulakshmi et al., 2009; Sharma et al., 2015; Karunakaran and Behera, 2015; Kumar et al., 2016). Dissemination of the CA based integrated weed management through onfarm demonstrations and providing the machinery on custom hiring basis are needed to popularize the technology and increased adoption by farming community across India.

In nutshell the weeds in CA can be managed effectively when system based integrated management including competitive cultivars were used with right agronomy and appropriate weed management practices adopted (Chauhan et al., 2012).

\section{Challenges and opportunities}

\subsection{Managing weeds under small farms}

Resources are limited for smaller land holding farmers in India. Weeding in India is normally done by use of manual labor even though currently herbicides are used, to a limited extent, in rice, wheat, soybean and tea. With estimated labor requirement of 20 man-days/ha for weeding, for weeding alone, India requires around 5 billion man-days of labor. Any shortage of labor will impact the weed management substantially. The National Rural Employment Guarantee scheme implemented in India has its impact on the availability of labor for agricultural operations in rural India. If such schemes are implements, irrespective of their usefulness the labor shortage will increase and thus wages will increase further in coming years (Yaduraju, 2012). Delayed weeding due to non availability of labor may result in severe crop losses and thus makes farmers to opt for herbicides usage in years to come to increase crop yield by managing weeds during critical period. Hence, the herbicides use is expected to grow in the near future.

The labor shortage is also making farmers to go for mechanization of agriculture activities like land preparation, weeding, harvesting and threshing, even in small farms by making use of machinery available at reasonable rates of rent in custom hiring centers as in Karnataka. Even a subsistence farmer finds using harvesters and tractors more economical. It is advisable to develop improvised mechanical weeding tools that are economically accessible to small and marginal farmers of India.

\subsection{Popularizing integrated weed management strategies with safe use of herbicides as a component}

It has been observed since green revolution era that single weed control method has not found sustainable and effective in long run. Managing weeds in an integrated manner using competitive cultivars right agronomy, which includes selecting a vigorous cultivar, appropriate nutrient and water management, using diversified rotations, cover crops, mulching and judicious use of herbicide when needed can make weed management in small farmers more effective and economical. Updating farmers' knowledge with timely, relevant, and accurate weed management technological information from time to time is crucial (Rao et al., 2014a). The herbicide use is increasing in India. However, the safe use of herbicides is not practiced in many states of India (Rao et al., 2015a). Hence training farmers on safe use of herbicides is a challenge to properly use the potentiality of herbicides as a component of integrated weed management. In order to ensure that farmers are equipped with the knowledge of the best weed management technologies to optimize long-term agricultural productivity in India, effective popularization, of the practices involved in safe use of herbicides, is essential. 


\subsection{Understanding weed biology and ecology and shift in weed population}

Shifts in weed flora have also been reported due to changes in the crop production practices (Yaduraju and Kathiresan, 2003; Malik and Kumar, 2014). Climate change will have its own impact on weeds, weed competitiveness against weeds, herbicide efficacy (Singh et al., 2011; Kathiresan and Gualbert, 2016). Thus, it is essential to have a proper understanding of the weeds, weed biology and the shifts in weed population that occur due to changes in crop management practices and the climate change. Hence, it is a great challenge to weed scientists to evolve better weed management options based on understanding of weed biology in the era of climate change.

\subsection{Herbicide resistant (HR) weeds and their management}

The repeated use of herbicides, in wheat in India, exerting strong selection pressure on crop weeds, has led to herbicide resistance in weeds such as Phalaris minor to PSII inhibitor (Ureas and amides) (C2/ 7) herbicides (1991); ACCase inhibitors (A/1) (1994); multiple resistance at 3 Sites of Action: ACCase inhibitors (A/1), ALS inhibitors (B/ 2), PSII inhibitor (Ureas and amides) (C2/7) (2006); ALS inhibitors (B/ 2)(2013) (as reported by Samunder Singh and R. Chhokar in www. weedscience.org). Rumex dentatus has evolved metsulfuron resistance (ALS inhibition) and also showed the cross-resistance to mesosulfuron + iodosulfuron, pyroxsulam, halauxifen + florasulam, while Polypogon monspeliensis was found to be resistant to sulfosulfuron, mesosulfuron, pyroxsulam (Chhokar et al., 2015). Herbicides will be a dominant weed-management tool in India in coming years and with increased reliance on herbicides and process of herbicide resistant (HR) weeds occurrence is likely to accelerate in farmers fields making weeds management a more serious challenge in India. An understanding of the evolutionary forces is essential to help slow the rate of the evolution of herbicide tolerance among weeds and for devising comprehensive weed management strategies. The best management practices (BMPs) for HR weed management in India are to be established.

\subsection{Limited infrastructure for weed management}

Proper weed management technology development and dissemination and adoption requires proper research and extension infrastructure. Availability of research infrastructure (for example: research laboratories with suitable equipment for various disciplines of Weed Science, appropriate field facilities, proper communication facilities) at various research stations plays an important role in researchers developing location specific weed management technologies. Hence, it needs to be strengthened further in India. Infrastructure facilities for proper demonstration of the available weed management technology for farming community by extension staff (for example: facilities for ecommunication with scientists and farmers, conduction of on-farm demonstrations, decision making tools preparation and dissemination, weed management modules (audio-video) preparation, display and distribution) and for farmers (for example: accessing the equipment, herbicides and other tools of weed management, and decision making tools) to adopt the technology developed and demonstrated are equally important.

\subsection{Institutional issues for appropriate weed management technologies development and adoption}

Transfer of technology programs are to be launched and strengthened with emphasis on on-farm evaluation of weed management technologies, their adoption and impact assessment. This would help increased adoption of available location specific weed management technologies by farming community across India.

\subsection{Role of private sector in weed management}

Private sector has played and is playing a key role in managing weeds in India. Herbicide industry and weed scientists have a greater combined responsibility of educating the farmers and the extension staff on judicious, proper and sustainable use of herbicides. Herbicides based research should focus on herbicide efficiency enhancement and integration of herbicide use with ecological methods of weed management. The development of innovative products, processes and concepts by entrepreneurs and private players and their integration into existing agricultural systems is the pathway to true inclusive agricultural growth (Yaduraju, 2012).

The private sector needs to be more sensitive towards the needs of small farmers in India. Farmers need simple packages of practices that can be adapted and outscaled easily. Therefore, an integrated weed management wherein herbicides dovetailed with other non-chemical weed management methods will provide lasting solutions for present and emerging weed issues. The agro-business houses need to play a proactive role in capacity building of farmers and extension agents with respect to compatibility among different herbicides and pesticides, herbicide application technologies and need of herbicide rotation. These capacity building efforts will not only enhance the efficiency and impact of herbicidal technologies but also restrict problems such as resistance weeds etc.

\subsection{Using bioagents and to integrate them with other weed management practices}

Keeping in view of major concerns of pesticide use such as environmental pollution, food and water contamination and development of pesticides resistance by several pest species, the AICRP in Biological Control of crop pests and weeds was initiated by Indian Council of Agricultural Research (ICAR), during the year 1977 to develop ecofriendly biological control methods for the sustainable management of pests. It was elevated to Project Directorate of Biological Control in 1993. Maximum of success with classical biological control agents in India has been achieved in biological control of aquatic weeds (55.5\%) followed by homopterous pests (46.7\%) and terrestrial weeds (23.8\%) (Paul et al., 2015).

A reduction in weed population by $50 \%$ and increase in the rice production by $5 \%$ was observed with introduction of herbivorous fish (Sarangi et al., 2004). A major constraint in rice-fish integration is the competition for nutrients among rice, weeds and fish which can be overcome and systems success can be achieved by suitable species combination selection, carrying capacity based stocking density, periodic fertilization and liming, high energy supplemented feeding and monitoring of water and quality.

The biocontrol tool was found effective in certain instances and not in other cases. The reasons behind the non-efficacy are to be studied in detail. The ways and means of integrating biocontrol with other methods also should be explored.

\subsection{Herbicide-resistant crops (HRC)}

Herbicide resistant crops are yet to be made available to farmers (Rajkumara and Lamani, 2007) for enabling them to use as component of integrated weed management. Bt-cotton is the only GM crop that has been approved for commercial cultivation during 2002 in India. It was accepted by all cotton growing farmers of India with nearly $86 \%$ of the total cotton area cultivated by over 5.6 million farmers, including small and medium farmers. About a thousand hybrids and one variety belonging to six different types (events) of Bt-cotton are available to the farmers. The technology has resulted in $40-60 \%$ reduction in pesticide use with $50-130 \%$ increase in farmers' profit and a significant increase in employment opportunities, particularly to women (Yaduraju, 2012).

HRC have the potential to improve the efficiency of weed 
management efficiency and facilitate resource conservation technologies (RCTs) adoption in India. Once the HRCs are introduced in India by private sector, integration of it with resource conservation tillage strategies will benefit the Indian farmers and will address productivity, profitability and sustainability issues in crop production. However, important risks associated with HRCs, such as the potential transfer of the gene conferring the HR trait to related wild and weedy relatives, should be examined thoroughly prior to their permission for wide spread adoption.

The bio-safety concerns that are to be addressed include: possible development of super weeds due to transgene movement to other varieties and wild relatives; genetic diversity erosion; ecological disturbance; adverse impact on non-target organisms; emergence of more virulent forms of weeds, pests and pathogens. It is essential to develop capacity building programs for extension workers and farmers in transgenic technology and its proper use with prudent compliance of biosafety measures.

\subsection{Preventing and managing invasive weeds}

In India, 173 invasive alien species belonging to 117 genera and 44 families, representing $1 \%$ of the Indian flora, were reported (Reddy, 2008). Most of them were introduced from tropical America (74\%) and tropical Africa (11\%). Invasive alien species are non-native organisms which cause, or have the potentiality to cause harm to the environment, economics, or human health.

Of several invasive exotic weeds reported from India, the weeds of major concern are: P. hysterophorus, L. camara (Nanjappa et al., 2005), A. conyzoides (Bajwa et al., 2016), E. crassipes, M. micrantha (Banerjee and Dewanji, 2012) and P. minor (Mahajan and Brar, 2001) as they are troublesome and have caused immense adverse ecological, economic and social impact. They have infested different landscapes and are luxuriantly localized in road sides, forests and cultivated areas. $P$. hysterophorus is the most troublesome and noxious weed which rapidly colonized urban areas replacing the native vegetation causing a number of human health problems (skin allergy, rhinitis and irritation to eyes of the residents in the vicinity) (Bajwa et al., 2016). P. hysterophorus is unpalatable and toxic to livestock. Currently $P$. hysterophorus became a major weed in upland crops of India as well. L. camara, has invaded larger areas of land in the Indian forests replacing the forest floor vegetation and causing reduced tree growth. Ageratum conyzoides is currently major weed in agricultural fields and competes with crops causing severe loss of yield of major crops of India. When it invades rangeland areas, it out competes native grasses on infesting rangelands and causes fodder scarcity. These weeds have similar growth strategies such as fast growth rates, short life-cycles, greater reproductive potential, high competitive abilities and allelopathy that make them successful invaders of native habitats.

A better understanding of the interaction of physiological processes, ecological functions, and genetic makeup within a range of environments may help to devise an appropriate management strategies for invasive weeds. The development of herbicide resistance in weeds e.g. P. minor in the 1990s (Sanbagavalli et al., 2000); growing menace of weedy rice in many states (Ramachandiran and Balasubramanian, 2012; Abraham and Jose, 2014) and Orobanche in mustard growing areas; invasion by alien weeds like Parthenium, Lantana, Ageratum, Chromolaena, Mikania and Mimosa in many parts of the country; impending climate change favouring more aggressive growth of weed species, and herbicide residue hazards are some of the major issues of concern.

\section{Conclusion}

The weed management technologies are available for managing weeds of different ecosystems. Fine tuning of the available technologies are needed to make the available technologies suit to the location specific needs of the farming community and others. There is need for extending infrastructure facilities for research, extension and adoption of weed management. The need based basic research on weed biology and ecology is to be emphasized for evolving location specific integrated weed management strategies through collaborative research with other disciplines of agriculture. Greater interaction with international institutions and weed scientists from around the world by Indian scientists is essential for solving the weed management problems in the era of climate change. The role of private sector is very critical in large scale adoption of integrated weed management programs in different crops. They need to understand that herbicide are only a tool in managing weeds and there are several other factors considered in developing and deploying weed management program. A system based weed management program using vigorous cultivar, appropriate agronomy and land management, suitable application technology and proper rotation of herbicide will provide lasting solution to small farmers in India.

\section{Acknowledgement}

A.N. Rao extends his thanks to Government of Karnataka, India for the financial assistance (BhooSamrudhi).

\section{References}

Abraham, C.T., Jose, N., 2014. Weedy rice invasion in rice fields of India and management options. J. Crop and Weed 10, 365-374.

Angiras, N.N., Chopra, P., Kumar, S., 2010. Weed seed bank and dynamics of weed flora as influenced by tillage and weed control methods in maize (Zea mays L.). Agric. Sci. Digest 30, 6-10.

Annadurai, K., Puppala, N., Angadi, S., Chinnusamy, C., 2010. Integrated weed management in groundnut based intercropping system- A review. Agric. Rev. 31, 11-20.

Arya, S.R., Ameena, M., 2016. Efficacy of new generation herbicides for weed management in semi dry rice. J. Trop. Agric. 54, 55-59.

Bahadur, S., Verma, S.K., Prasad, S.K., Madane, A.J., Maurya, S.P., Gaurav, V.K.V., Sihag, S.K., 2015. Eco-friendly weed management for sustainable crop production - a review. J. Crop and Weed 11, 181-189.

Bajwa, A.A., Chauhan, B.S., Farooq, M., Shabbir, A., Adkins, S.W., 2016. What do we really know about alien plant invasion? A review of the invasion mechanism of one of the world's worst weeds. Planta 244, 39-57.

Banerjee, A.K., Dewanji, A., 2012. Mikania micrantha H.B.K. - a potential and economical threat to global biodiversity with special emphasis on Indian context. Conference paper. In: Developing Solutions to Evolving Weed Problems. 18th Australasian Weeds Conference, Melbourne, Victoria, Australia, 8-11 October 2012, pp. pp.17-20.

Barua, I.C., Deka, J., Devi, M., Deka, R.L., Moran, J., 2017. Weeds as emerging threat to biodiversity: a consequence of spread of Ludwigia peruviana in Dhansiri and Kopili catchment areas of Assam, North East India. Current Sci. 112, 1904-1914.

Bera, P.S., Mandal, A., Bandyopadhyay, S., Kundu, C.K., Patra, B.C., Gunri, S.K., 2016. Influence of drum seeding and non-chemical weed management at different times in Boro rice production. Environ. Ecol. 34, 2509-2513.

Bhan, V.M., Sushilkumar, 1998. Weed science research in India. Indian J. Agric. Sci. 68 , 567-582.

Bhadoria, P.B.S., 2011. Allelopathy: a natural way towards weed management. Am. J. Exp. Agric. 1, 7-20.

Brar, A.S., Walia, U.S., 2009. Weed dynamics and wheat (Triticum aestivum L.) productivity as influenced by planting techniques and weed control practices. Indian J. Weed Sci. 41, 161-166.

Bhullar, M.S., Kamboj, A., Singh, G.P., 2006. Weed management in spring planted sugarcane-based intercropping system. Indian J. Agron. 51, 183-185.

Bhuvaneswari, J., Chinnusamy, C., Sangeetha, S.P., 2010. Evaluation of non-chemical methods of weed management in organically grown maize-sunflower cropping system. Madras Agric. J. 97, 242-244.

CGIAR, 2017. https://cgspace.cgiar.org/bitstream/handle/10568/71051/SBSTA44Agricultural-practices-technologies.pdf. accessed on May 31, 2017.

Chadha, K.L., Leela, D., Challa, P., 1997. Weed management in Horticulture and Plantation Crops. Malhotra Publishing House, New Delhi.

Chandrasena, N., Rao, A.N., 2017. Asian-pacific weed science society: a glimpse of the past 50 Years and perspectives. In: Chandrasena, N., Rao, A.N. (Eds.), Commemorating 50 Years (1967-2017). 50th Anniversary Celebratory Volume. Asian-Pacific Weed Science Society (APWSS); Indian Society of Weed Science (ISWS), India and The Weed Science Society of Japan (WSSJ), Japan, pp. 1-38.

Chhokar, R.S., Sharma, R.K., Sharma, I., 2015. Herbicide resistant weeds and their management in wheat. In: Proc. 25th Asian-Pacific Weed Sci. Soc. Conf. On "Weed Science for Sustainable Agriculture, Environment and Biodiversity", Hyderabad, India, pp. 141.

Choudhury, P.P., Singh, R., 2015. Role of herbicides in agriculture. Indian Farming 65, 66-72.

Choudhury, P.P., Singh, R., Ghosh, D., Sharma, A.R., 2016. Herbicide use in Indian 
agriculture. In: ICAR - Directorate of Weed Research, Jabalpur, Madhya Pradesh, pp. 110.

Chauhan, B.S., Mahajan, G., 2012. Role of integrated weed management strategies in sustaining conservation agriculture systems. Current Sci. 103, 135-136.

Chauhan, B.S., Singh, R.G., Mahajan, G., 2012. Ecology and management of weeds under conservation agriculture: a review. Crop Protect. 38, 57-65.

Das, T.K., Yaduraju, N.T., 2008. Effect of soil solarization and crop husbandry practices on weed species competition and dynamics in soybean-wheat cropping system. Indian J. Weed Sci. 40, 1-5.

Das, T.K., Yaduraju, N.T., 2007. Effect of irrigation and nitrogen levels on grassy weed competitionin wheat and comparative eco-physiology of Phalaris minor Retz. and Avena sterilis ssp. leudoviciana in wheat. Indian J. Weed Sci. 39, 178-184.

Das, T.K., Tuti, M.D., Sharma, R., Paul, T., Mirja, P.R., 2012. Weed management research in India: An overview. Indian J. Agron. 57, 148-156.

Datta, S., Mahapatra, B., Sardar, P., 2014. Search for a herbicide suitable for controlling submerged aquatic weeds under Indian condition. Indian J. Anim. Res. 48, 473-479.

Deka, J., Barua, I.C., Borah, N., Deka, N.C., 2013. Weed flora and their management in aquatic environments of Assam, India. In: Proc. 24th Asian-Pacific Weed Sci. Soc. Conf., Bandung, Indonesia, October 22-25, 2013. Weed Science Society of Indonesia, Bandung, Indonesia, pp. 227-234.

Dixit, A., Varshney, J.G., 2009. Herbicide Use in Field Crops. Directorate of Weed Science Research, Jabalpur, India.

Dixit, A., Varshney, J.G., 2009a. Handbook on Herbicide Recommendations. Directorate of Weed Science Research, Jabalpur, India.

Dixit, A., Gogoi, A.K., Varshney, J.G., 2008. Weed Atlas. (District Wise Distribution Pattern of Major Weed Flora in Prominent Crops). NRCWS (ICAR), Jablapur, Madhya Pradesh, India Vol. I and Vol. II.

Duary, B., Mukherjee, A., Bhowmick, M.K., 2015. Phyto-sociological attributes of weed flora in major crops of red and lateritic belt of West Bengal. Indian J. Weed Sci. 47, 89-92.

DWR, 2015. Vision 2050. Directorate of Weed Research. Indian Council of Agricultural Research, Jabalpur 482 004, Madhya Pradesh.

FAO, 2017. http://www.fao.org/climatechange/35137-01475a57da304df922b9ea 292fddc 29fa.pdf. Accessed on May 30, 2017.

Gajbhiye, K.S., Mandal, C., 2006. Agro-ecological Zones, Their Soil Resource and Cropping Systems. National Bureau of Soil Survey and Land Use Planning, Nagpur, India.

GOI, 2012. A Users Compendium on Small Agricultural Machinery and Implements (State/Region/Agroclimatic Zones Specific Low Cost, Light Weight, Compact, Multi Utility Farm Machinery and Implements Affordable to Small and Marginal Farmers. Government of India, Ministry of Agriculture, Department of Agriculture \& Cooperation, Krishi Bhawan, New Delhi, India.

Goswami, S.B., Saha, S., 2006. Effect of organic and inorganic mulches on soil moisture conservation, weed suppression and yield of elephant-foot yam. Indian J. Argon. 51, 154-156.

Hobbs, P.R., Gupta, R.K., 2003. Resource-conserving technologies for wheat in the ricewheat system. In: Ladha, J.K., Hill, J.E., Duxbury, J.M., Gupta, R.K., Buresh, R.J. (Eds.), Improving the Productivity and Sustainability of RiceWheat Systems: Issues and Impacts. ASA Special Publication Number: 65. ASACSSA-SSSA, Madison, Wisconsin, USA, pp. 149-172.

Hussain, K., Ahmed, N., Nazir, G., Bhat, K., Mustaque, 2007. Integrated weed management in vegetables. Review. Tha Asian J. Hort. 2, 234-241.

ICARDA, 2017. http://www.icarda.org/conservation-agriculture-mitigating-effectsclimate-change. Accessed on May 31, 2017.

ILO, 2016. India labour market update - ILO country office for India, July 2016. In: International Labor Organisation (ILO), ILO Decent Work Team for South Asia and Country Office for India, New Delhi, India.

Jayanth, K.P., 2000. Biological control of weeds in India. pp 207-221. In: Upadhyay, Rajeev, K., Mukerji, K.G., Chamola, B.P. (Eds.), Chapter, Biocontrol Potential and its Exploitation in Sustainable Agriculture. Crop Diseases, Weeds, and Nematodes. Kluwer academic/Plenum publishers, Newyork, USA.

Jat, R.S., Meena, H.N., Singh, Surya, J.N., Misra, J.B., 2011. Weed management in groundnut (Arachis hypogaea L.) in India - a review. Agric. Rev. 32, 155-171.

Jeyaraman, S., Karamathullah, J., Kannappan, K., Padmanabhan, D., 2002. Weed management studies in sugarcane - a review. Cooper. Sugar 34, 207-217.

Joshi, N.C., 1971. Status of weed control in India. In: Proc. APWSS Conference, Malaysia, pp. $46-51$.

Karunakaran, V., Behera, U.K., 2015. Conservation agriculture in soybean (Glycine max) wheat (Triticum aestivum) cropping system-A review. Agric. Rev. 36, 169-183.

Kathiresan, R., Gualbert, G., 2016. Impact of climate change on the invasive traits of weeds. Weed Biol. Manag. 16, 59-66.

Kosaka, Y., Saikia, B., Mingki, T., Tag, H., Riba, T., Ando, K., 2010. Roadside distribution patterns of invasive alien plants along an altitudinal gradient in Arunachal Himalaya, India. Mt. Res. Dev. 30, 252-258.

Kumar, A., Kumar, S., Kamat, D.N., 2016. Resource conservation technology for weed management. Adv. Res. J. Crop Improv. 7, 176-179.

Kumar, A., Jai Kumar, J., Puniya, R., Mahajan, A., Sharma, N., Stanzen, L., 2015. Weed management in maize-based cropping system. Indian J. Weed Sci. 47, 254-266.

Kumar, P., Singh, Y., Singh, U.P., 2013. Evaluation of cultivars and herbicides for control of barnyardgrass and nutsedge in boro rice. Indian J. Weed Sci. 45, 76-79.

Ladha, J.K., Rao, A.N., Raman, A., Padre, A., Dobermann, A., Gathala, M., Kumar, V., Saharawat, Y., Sharma, S., Piepho, H., Alam, Md, Laik, R., Rajendran, R., Reddy, C., Prasad, R., Sharma, P., Singh, S., Saha, A., Noor, S., 2016. Agronomic improvements can make future cereal systems in South Asia far more productive and result in a lower environmental footprint. Global Change Biol. 22, 1054-1074.

Mahajan, G., Brar, L.S., 2001. Integrated management of Phalaris minor in wheat. Indian
J. Weed Sci. 33, 9-13.

Malik, R.K., Kumar, V., 2014. Zero tillage and management of herbicide resistance in wheat. In: Souvenir. Directorate of Weed Research, Jabalpur, India, pp. 64-70.

Manjunath, Rakesh Kumar, R., Kumar, S., Thakral, S.K., 2010. Effect of irrigation and weed management on lentil (Lens culinaris Medic. L.) under different planting techniques. Indian J. Weed Sci. 42, 56-59.

Masood Ali, Singh, K.K., Pramanik, S.C., Ali, M.O., 2009. Cropping systems and production agronomy. In: The Lentil: Botany, Production and Uses. CABI, Wallingford, UK, pp. 213-228.

Meher-Homji, V.M., 2005. Urban-tribal vegetation: a concept based on regional development. Indian J. For. 28, 213-215.

Mukherjee, P.K., Tomar, S.S., 2015. Weed flora and weed management practices in fodder crops. In: Proceedings, Volume III. 25th Asian-Pacific Weed Science Society Conference, Hyderabad, India. Indian Society of Weed Science, Jabalpur, India, pp. 295 13-16 October 2015.

Mukhopadhyay, S.K., 1993. Weed research in India and future thoughts. In: Proc. 10th Australian Weeds Conf./14th Asian-Pacific Weed Sci. Soc. Conf., Brisbane, Queensland, pp. 104-109.

Munirathnam, P., Kumar, K.A., 2014. Survey of weed flora in major crops of Nandyal region in Kurnool district of Andhra Pradesh. J. Res. ANGRAU 42, 142-146.

Nalini, K., Murhukrishnan, P., Chinnusamy, C., Vennila, C., 2015. Weeds of cotton - A review. Agric. Rev. 36, 140-146.

Nalini, K., Jayanthi, C., Vennila, C., 2008. Dual cropping in semidry rice - A review. Agric. Rev. 29, 151-156.

Nanjappa, H.V., Saravanane, P., Ramachandrappa, B.K., 2005. Biology and management of Lantana camara L. - A review. Agric. Rev. 26, 272-280.

Nayak, B.N.S., Khan, M.M., Mosha, K., Rani, P.P., 2014. Effect of planting density and weeding regime on yield attributes and yield of drum seeded rice (Oryza sativa L.). Int. J. Agric. Inn. Res. 2, 753-760.

Nithya, C., Chinnusamy, C., Ravisankar, D., 2013. Weed management in herbicide tol erant transgenic cotton (Gossypium hisrsutum L.) - a review. Int. J. Agric. Sci. Res. (IJASR) 3, 277-284.

Panneerselvam, S., Lourduraj, A.C., 2000. Weed spectrum and effect of crop weed competition in soybean [Glycine $\max$ (L.) Merrill], a review. Agric. Rev. 21, 121-124.

Patel, R.H., Shroff, J., Dutta, S., Meisheri, T.G., 2005. Weed dynamics as influenced by soil solarization - A review. Agric. Rev. 26, 295-300.

Paul, B., Shankarhanesh, K., Suroshe, S., 2015. Biological control for pest management. In: Dhillon, M.K., Gujar, G.T. (Eds.), Souvenir and Abstracts of the National Symposium on "Integrated Pest Management for Sustainable Crop Protection", 24-25 February, 2015. Division of Entomology, ICAR-Indian Agricultural Research Institute, New Delhi-110 012, India, pp. 15-16.

Priya, R.S., Chinnusamy, C., Manickasundaram, P., Babu, C., 2013. A review on weed management in groundnut (Arachis hypogea L.). Int. J. Agric. Sci. Res. (IJASR) 3, $163-172$.

Punia, S.S., Yadav, D., Amarjeet, Sindhu, V., 2017. Investigations on weed flora of wheat in Haryana. Agric. Res. J. 54, 136-138.

Punia, S.S., Singh, S., Yadav, A., Yadav, D.B., Malik, R.K., 2016. Long-term impact of crop establishment methods on weed dynamics, water use and productivity in rice-wheat cropping system. Indian J. Weed Sci. 48, 158-163.

Rabindra, R.J., Kumar, P.S., Verghese, A., 2017. Policy frameworks for the implementation of a classical biological control strategy: the Indian experience. In: Ellison, C.A., Sankaran, K.V., Murphy, S.T. (Eds.), Invasive Alien Plants: Impacts on Development and Options for Management. CABI, Wallingford, UK, pp. 206-217.

Rajkumara, S., Lamani, K.D., 2007. Weed management in herbicide resistant crops - A review. Agric. Rev. 28, 56-62.

Rajendran, K., Lourduraj, A.C., 1999. Weed management in groundnut - a review. Agric. Rev. 20, 59-62.

Ramachandiran, K., Balasubramanian, R., 2012. Weedy rice and its management - A review. Agri. Rev. 173, 175-178.

Ramesh, K., Rao, A.N., Chauhan, B.S., 2017. Role of crop competition in managing weeds in rice, wheat, and maize in India: A review. Crop Protect. 95, 14-21.

Rao, A.N., Chauhan, B.S., 2015. Weeds and weed management in India - a review. In: Weed Science in the Asian Pacific Region. Indian Society of Weed Science, Jabalpur, India, pp. 87-118.

Rao, A.N., Nagamani, A., 2010. Integrated weed management in India - Revisited. Indian J. Weed. Sci. 42, 1-10.

Rao, A.N., Nagamani, A., 2007. Available technologies and future research challenges for managing weeds in dry-seeded rice in India. In: Marambe, B., Sangakkara, U.R., De Costa, W.A.J.M., Abeysekara, A.S.K. (Eds.), Proc. 21st Asian Pacific Weed Sci. Soc. Conf., 2-6 October 2007, Colombo, Sri Lanka, pp. 391-401.

Rao, A.N., Ladha, J.K., Wani, S.P., 2015. Weeds and weed control in finger millet in India - a review. In: Proc. 25th Asian-Pacific Weed Sci. Soc. Conf. on "Weed Science for Sustainable Agriculture, Environment and Biodiversity", during 13-16 October, 2015, Hyderabad, India, pp. 114.

Rao, A.N., Wani, S.P., Ramesha, M., Ladha, J.K., 2015a. Weeds and weed management of rice in Karnataka State, India. Weed Technol. 29, 1-17.

Rao, A.N., Wani, S.P., Ladha, J.K., 2014. Weed management research in India - an analysis of the past and outlook for future. In: Souvenir (1989-2014). DWR Publication No. 18. Directorateof Weed Research, Jabalpur, India, pp. 1-26.

Rao, A.N., Malik, R.K., Yadav, A., Ladha, J.K., 2014a. Strengthening farmers' knowledge for better weed management in developing countries. pp. 991-405. In: Chauhan, B.S., Mahajan, G. (Eds.), Recent Advances in Weed Management. Springer, USA.

Rao, A.N., Johnson, D.E., Sivaprasad, B., Ladha, J.K., Mortimer, A.M., 2007. Weed management in direct-seeded rice. Adv. Agron. 93, 153-255.

Reddy, S.C., 2008. Catalogue of invasive alien flora of India. Life Sci. J. 5, 84-89.

Reddy, K.N., Jha, P., 2016. Herbicide-resistant weeds: management strategies and 
upcoming technologies. Indian J. Weed Sci. 48, 108-111.

Sanbagavalli, S., Kandasamy, O.S., Ganesan, K., 2000. Herbicide resistance in weeds: A review. Agric. Rev. 21, 80-88.

Sankaran, K.V., 2017. Control options for invasive alien plants in agroforestry in the AsiaPacific region. In: Ellison, C.A., Sankaran, K.V., Murphy, S.T. (Eds.), Invasive Alien Plants: Impacts on Development and Options for Management. CABI, U.K, pp. 138-161.

Sarangi, S.K., Sharma, H.C., Sharma, G., 2004. Rice-fish farming system - A review. Agric. Rev. 25, 49-56.

Satyareddi, S.A., Devasenapathy, P., Chinnusamy, C., Kaleeshwari, R.K., Mynavathi, V., 2015. Influence of non chemical weed management practices on nutrient uptake in sunflower and weeds. Trends in Biosci. 8, 3503-3507.

Sharma, A.R., Das, T.K., Behera, U.K., 2015. Conservation agriculture systems and weed management. Indian Farming 65, 7-13.

Singh, S.P., 2004. Some Success Stories in Classical Biological Control in India. AsiaPacific Association of Agricultural Research Institutions (APAARI). FAO regional office for the Asia Pacific, Bangkok, Thailand.

Singh, S.P., 2001. Biological control of invasive weeds in India. In: Sankaran, K.V., Murphy, S.T., Evans, H.C. (Eds.), Alien Weeds in Moist Tropical Zones: Banes and Benefits. Proceedings of a Workshop, Kerala Forest Research Institute, Peechi, India, 2-4 November 1999. Kerala Forest Research Institute, Peechi, India, and CABI Bioscience, UK Centre (Ascot), Ascot, UK, pp. 11-19.

Singh, R., Das, T.K., Kaur, R., Raj, R., Shekhawat, K., 2016. Weed management in dryland agriculture in India for enhanced resource use efficiency and livelihood security. Proc. Natl. Acad. Sci., India, Sect. B Biol. Sci. http://dx.doi.org/10.1007/s40011-0160795-y.

Singh, B., Dhaka, A.K., Pannu, R.K., Kumar, S., 2013. Integrated weed management-a strategy for sustainable wheat production - A review. Agric. Rev. 34, 243-255.

Singh, R.K., Singh, R.P., Singh, M.K., 2013a. Weed management in rapeseed-mustard - A review. Agric. Rev. 34, 36-49.

Singh, S., Ladha, J.K., Gupta, R.K., Lav Bhushan, Rao, A.N., Sivaprasad, B., Singh, P.P., 2007. Evaluation of mulching, intercropping with Sesbania and herbicide use for weed management in dry-seeded rice (Oryza sativa L.). Crop Protect. 26, 518-524.

Singh, R.P., Singh, R.K., Singh, M.K., 2011. Impact of climate and carbon dioxide change on weeds and their management-A review. Indian J. Weed Sci. 43, 1-11.

Sridhar, H.S., 2013. Development of single wheel multi use manually operated weed remover. Int. J. Mod. Eng. Res. (IJMER) 3, 3836-3840.
Sondhia, S., 2014. Herbicides residues in soil, water, plants and non-targeted organisms and human health implications: an Indian perspective. Indian J. Weed Sci. 46, 66-85.

Subbulakshmi, S., Saravanan, N., Subbian, P., 2009. Conventional tillage vs conservation tillage - A review. Agric. Rev. 30, 56-63.

Subudhi, H.N., Panda, S.P., Behera, P.K., Patnaik, C., 2015. A check list of weeds in rice fields of coastal Orissa. India.J. Agric. Sci. 7, 207-216.

Sumathi, V., Subramanyam, D., Rao, D.S.K., Reddy, D.S., 2010. Effect of planting pattern and weed management on weed flora and yield of rabi sunflower. Indian J. Weed Sci. 42, 212-216.

Sunitha, N., Kalyani, D.L., 2012. Weed management in maize (Zea mays L.) - A review. Agri. Rev. 33, 70-77.

Sushilkumar, 2011. Aquatic weeds problems and management in India. Indian J. Weed Sci. 43, 118-138.

Sushilkumar, Ray, P., 2011. Evaluation of augmentative release of Zygogramma bicolorata for biological control of Parthenium. Crop Protect. 30, 587-591.

Sushilkumar, Saraswat, V.N., 2001. Integrated management: the only solution to suppress Parthenium hysterophorus. In: Sankaran, K.V., Murphy, S.T., Evans, H.C. (Eds.), Alien Weeds in Moist Tropical Zones: Banes and Benefits. Proceedings of a Workshop, Kerala Forest Research Institute, Peechi, India, 2-4 November 1999. Kerala Forest Research Institute, Peechi, India, and CABI Bioscience, UK Centre (Ascot), Ascot, UK, pp. 150-168.

Trivedi, G.C., Patel, R.B., Patel, B.D., Meisuriya, M.I., Patel, V.J., 2000. Some problematic weeds and their management - A review. Agric. Rev. 21, 238-243.

Verma, S.K., Singh, S.B., Rai, O.P., Singh, G., 2008a. Effect of mulching and irrigation on weeds and yield of summer green gram in saline soil. Indian J. Agri. Sci. 78, 1082-1085.

Verma, S.K., Singh, S.B., Rai, O.P., Sharma, R., Singh, G., 2008. Effect of cultivars and herbicideson yield and nutrient uptake by weed and wheat under zero-tillage system. Indian J. Agri. Sci. 78, 984-987.

Vijayakumar, M., Jayanthi, C., Kalpana, R., Ravisankar, D., 2014. Integrated weed management in sorghum [Sorghum bicolor (L.) Moench] - A review. Agri. Rev. 35, 79-91.

Yaduraju, N.T., 2012. Weed management perspectives for India in the changing agriculture scenario inthe country. Pakistan J. Weed Sci. Res. 18, 703-710.

Yaduraju, N.T., Kathiresan, R.M., 2003. Invasive weeds in the tropics. In: Proc. 19th Asian-Pacific WeedSci. Soc. Conf., Manila, Philippines, vol. I. pp. 59-68. 